\title{
MARKETING COMMUNICATION STRATEGY THROUGH SOCIAL MEDIA TO INCREASE CHILDREN BOOK SALES
}

\author{
Marina Wardaya \\ Visual Communication Design Department, Creative Industries Faculty of Ciputra University \\ UC Town, Citraland Surabaya \\ marina.wardaya@ciputra.ac.id
}

\begin{abstract}
The purpose of this research was to determine the marketing communication strategy of children's books through social media in increasing sales. Qualitative research methods with the interpretive paradigm and the phenomenological approach were used in this research. The focus of this research was to observe about the children's books marketing communication strategy using social media, for instance with Facebook and Twitter to attract consumer's interest in order to increase children's books sales. The results of this study show that the children's book marketing communication strategies in publisher's social media are fully and interactively utilized, as seen from the various activities posted on Facebook and Twitter. As well as the positive response from consumers who show their interest and desire to buy books offered or follow the event being held in order to increase sales.
\end{abstract}

Keywords: marketing communication strategy, social media, Facebook, Twitter, children's books, publishers

\section{INTRODUCTION}

The growing awareness of parent's toward pre-school education encourages parents to pay more attention. One of the learning media is the book. Children's books with educational elements are developing since the book is seen as a medium of learning. Theoretically learning can indeed be started since preschool-aged children that are better known as PAUD (Early Childhood Education). The children at this age have the characteristics of development that enable them to take the lesson. Currently, the children's book publishing market with the elements of education is increasing. Many large and small publications are competing to publish various types of children's books with educational elements. It is from children's textbooks to the fairy tale-themed children's books.

By the end of 2010, it has been recorded that Gramedia has 100 Bookstore branches throughout Indonesia. The average of each store presents 30 thousand titles of books, both locally and translated. Several other major publishing that leads market genre for instance BIP and Elex Media, both are a subsidiary company of the Kompas Gramedia Group (KGG). In the books purchasing, parents as consumers have very important role in a matter of whether a children's book with the elements of education or not, since the parent's role as the final decision maker of the purchase.

Book publisher's challenge today is quite substantial. Besides thepublic reading interest, it is also the digitalization era, which children are more interested in playing gadget than reading the book. Companies that specialized in book publishing, especially in children's books, they are required to think and to act effectively and efficiently in attracting consumers to buy children's books and increase book sales in this digitalized era. The company's success in marketing the product mostly depends on company method in communicating with consumers. Communication is the process by which a person (communicator) conveysstimulant to change the behavior of others (Arifin, 2006). 
Based on the definition of communication, it can be observed that besides providing information, the communication also gives effect to the communicants to act according to what is expected by the communicator.

For an organization or company, communication is appropriately used to deliver messages to customers that related with the brand and the produced and promoted products. The communication used is a marketing communications. This communication has an important role in the process of development and building awareness of a product. Kevin Keller in (Belch \& Belch, 2011) has stated that managing brand awareness, has become a priority for companies of all sizes, in all types of industries and markets.

The development and advancement of the current information technology bring changes in many things especially in terms of communication. Communication itself could be interpreted as a form of human interaction that affects each other to one another, whether either intentionally or unintentionally. And it is not limited to the form of communication using verbal language and the other way such as the facial expressions, painting, art and technology as presented by Shannon \& Weaver (Cangara, 2012).

Nowadays, lots of technology that support communication media, one of them is the development of the Internet. The Internet invention is a major innovation which eventually give seasiness to users as a medium for communication that is efficient, effective, and cheap. Kartajaya (2010) has stated that the progress of the current technology makes the marketer activities experienced a functional change where consumers have sufficient information and can compare various offer in a wide variety of similar products. This means that each customer candidates is easier to determine which products that are similar and the best for them. It is becoming one of the shifting roles of consumers that from the once-isolated become the interconnected. Besides that the consumers get enough information as a basis for making decisions. Social media becomes a platform as a gathering place for individuals to create a group and expand the connections. Along with the development of technology, social media presence currently is not only used to communicate with other people, but also to be used as marketing media and online business promotion (Hutter, Hautz, Dennhardt, \& Füller, 2013).

Therefore, the researcher examines the children's book marketing communication strategy through social media that related to marketing strategies which attract customers to buy. The purpose of this study is to determine how the marketing communication strategy of children's books through social media in increasing sales. The problem statement in this research that designated as the research subject is how children book marketing communication strategies through social media in increasing sales.

\section{METHODS}

This research uses the descriptive method. In a descriptive research, the emphasis is data analysis by observing the processes of the occurrence phenomenon. Descriptive qualitative research according to Mayer and Greenwood (Silalahi, 2009) simply refers to the identification of properties that distinguish or characteristic of a group of people, objects, or events.

This descriptive qualitative research describes the phenomenon of social media as a promotional media. The type of data in this research are interviews (depth interview) in the form of qualitative data, namely data that is in the form of words or verbal statements, opinions, attitudes, 
motives; trust perceptions, behavior, facts, attributes, and knowledge about social media usage as a children's book promotional tool on Facebook and Twitter.

The source of the data obtained from the primary data which is obtained from the answers results that given by the speakers from the interview result. The primary data are in the form of statements, interpretation, activities, and observations that are done by the perpetrators of speakers in promoting children's books. And secondary data is obtained from the experts, literature, library, the bulletins, and the internet which are directly related to information about the use of social media as a means of promotional means. It becomes the object of the research and for the preparation of this research report (Moleong, 2014).

\section{RESULTS AND DISCUSSIONS}

Communication is the relationship of contact between and among humans both individuals and groups. In daily life whether it is realized or not, communication is a part of human life itself. Since the humans were born, they already communicate with their surroundings. Moreover, the communication is also interpreted as relationships or activities that are related to public relations or exchanging thoughts and opinions (Widjaja, 2000).

According to Carl I. Hovland (Widjaja, 2000), communication studies is systematic effort to explicitly formulate the principles of information delivery as well as the opinions and attitudes formation. Hovland definition above shows that the object of communication studies is not only the delivery of information, but also the formation of public opinion, and public attitudes that play a very important role in social life and political life. Even in its definition on the meaning of the communication itself, Hovland has said that communication is the process of changing the behavior of others or communication is the process to modify the behavior of other individuals (Widjaja, 2000).

To understand the meaning of communication that can be carried out effectively, communication enthusiasts often cite the paradigm that is proposed by Harold Lasswell in his work, The Structure and Function of Communication in Society. Laswell has said that a good way to describe communication is to answer the following questions; who says what in which channel to whom with what effect? (Effendy, 2009). According to Laswell (in Effendy, 2009) paradigm above shows that communication includes five elements which are communicators (communicator, source, sender), message, media (channel, media), communicant (communicate, receiver, recipient) and effect (impact, influence).

Therefore, based on the Laswell paradigm, communication is a message delivering process by the communicator to the communicant through media that cause certain effects (Effendy, 2009). It is emphasized that communication has a specific purpose and this purpose is certainly affecting the communicants to act accordingly to what communicators want. Communications provide something to others with specific contacts, or by using certain tools. With the communication, people can convey information, opinions, ideas, conceptions, knowledge, feelings, attitudes, actions and so forth to each other on a reciprocal basis, either as a communication sender or receiver.

The communication process is essentially a process of delivering thoughts or feelings by a person (communicator) to others (communicant). The mind can be in the form of an idea, information, opinions, and more that occur from his mind. Feelings can be in the form of faith, certainty, doubt, fear, anger and so forth that arise from the heart (Effendy, 2009). The communication process is divided into two stages; primary and secondary basis. The first stage is communication process in the primary. The primary communication process is the process of delivering thoughts and or feelings to 
others using an emblem (symbol) as media. The second stage is communication process in secondary. This secondary communication process is the process of delivering a message by one person to another by using a tool or means as a second media after the emblem used as the first medium (Effendy, 2009).

Communication is a process where thinking and understanding delivered between individuals, or between organizations with individuals. Marketing is a set of activities in which companies and other organizations transferring the values (exchange) among them with their customers. Certainly, the understanding of marketing is more general than marketing communications; however marketing activities involve more on communication activities. When combined, marketing communications represents all the elements in the brand marketing combination, which facilitates exchange by creating a meaning that is distributed to the customer or client (Shimp, 2003).

Marketing communications strategy is different from the communication strategy, the point of difference lies on both objectives. Marketing communications strategy has objectives related to the purpose of marketing itself. While the objective of communication strategy itself depends on what the communication strategy and for what purpose. On the other words of the communication strategy is the coverage of marketing communication strategy. Marketing communications strategy is different from the political communication strategy. However, both of them are the communication strategy to influence (persuasion) communicant yet with a different purpose (Cheung \& Lee, 2012).

Kotler and Keller have defined that marketing communications as the medium used by companies to inform, persuade, and remind consumers directly or indirectly about the products and brands they sell. In a certain sense, marketing communications represent the brand's "voice" and as a medium that can be used to initiate a dialogue and building relationships with consumers. The description of the stages that proposed by Kotler \& Keller (2009) are first stages, identify in message recipient target. Identification target of the message recipient from children book is the parents' work as the decision maker in purchasing children's books. The social media as the tool in promoting book, especially in children books can be seen in Figure 1.

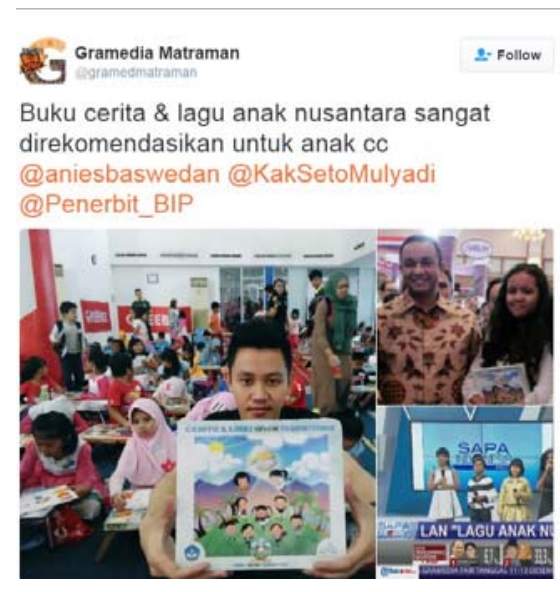

Figure1 Facebook Gramedia Pustaka Utama

(Source: Facebook.com/GramediaPublisher, 2016)

The second stage is determining the communication purpose. Response determination is part of specifying marketing communications purpose of the children's book. The cognitive response that company set down the perception in the consumers' minds about the products of the children's book as educational books that can help children or develop children's ability. The publisher is also trying 
to change the attitude of consumers concerning the children's book products as something that is essential in the children's development that is an effective response. The publisher also makes consumers do the actual act as a response to the consumer's act of purchasing.

The third stage is designing message. In developing an effective message, it is delivered by the publisher through Twitter and Facebook. Social media must contain elements of AIDA (Attention, Interest, Desire, Action), which has gained the consumers attentionby giving the message and display the latest preview pictures of the children's book edition. Itcould raise a sense of interest to children's books products by consumers. By posting the latest children's books, it stimulates the consumer's desire to buy children's books with preview story, replacing the book cover or the book preface thus finally do the purchasing (action). The example of children's books in one publisher (Gramedia) can be seen in Figure 2.

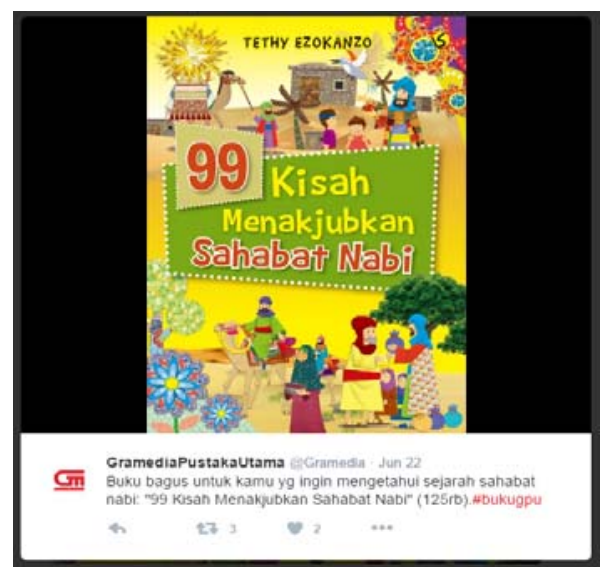

Figure 2 Children`s Book of Gramedia Pustaka Utama Source: Facebook.com/GramediaPublisher (2016)

Next step is choosing communication channels. According to Kotler (2007), there are several communication channels namely personal and non-personal communication. Communication that is done by the publisher through Twitter and Facebook is part of the non-personal communication. The messages that have been designed transferred through the twitters and Facebook. After choosing communication channels then companies can specify the total budget for communication. How do companies determine the promotional budget? There are four main methods used in formulating the promotional budget. The method is corresponding with the capability, sales presentation method, balance method competition, purposes and method of tasks.

Deciding the type of marketing communications will help company allocate promotional budget through the variety of promotional tools according to the effectiveness and efficiency. However through social media, publisher does not need to allocate promotional budget through promotional tools because there is almost no cost in delivering the message through twitter and Facebook fan page (Neti, 2011).

The next action that has to be done is measuring the effect that occurs on the message recipient target. That way can be done such as asking directly to consumers related to their memory of which from the delivered message, their intensity in observing the message, the most memorized part of the message, feelings and consumer attitude toward the message. This can be seen from the comments, mention or a tweet done by consumers on Facebook or Twitters (Brison, et al., 2016). 
Then with that data, the company can set up an integrated marketing communication process. Any forms of communication that have been done must be planned and integrated into the marketing communications program that carefully integrated. Based on the data findings, publisher in running marketing strategy implementation has already designed it carefully (Hassan, Zaleha, Nadzim, \& Shiratuddin, 2015).

The approach technique to affect consumer decision (Bruner \& Pomazal, 1988), one of them is the Response Stimulus Approach technique. This technique is the ideas or knowledge delivery technique of a brand and product to the consumers so that consumers are interested or motivated in making the decision to buy the products delivered. In other words, publishers provide a stimulus in the form of the latest children's books that they publish, then expecting that consumer to be able to respond positively. For example, a reader who asks the availability of children's books, then the consumers directed to buy or recommend the similar books. Therefore the reader is interested in buying the similar book. It can be seen in Figure 3.

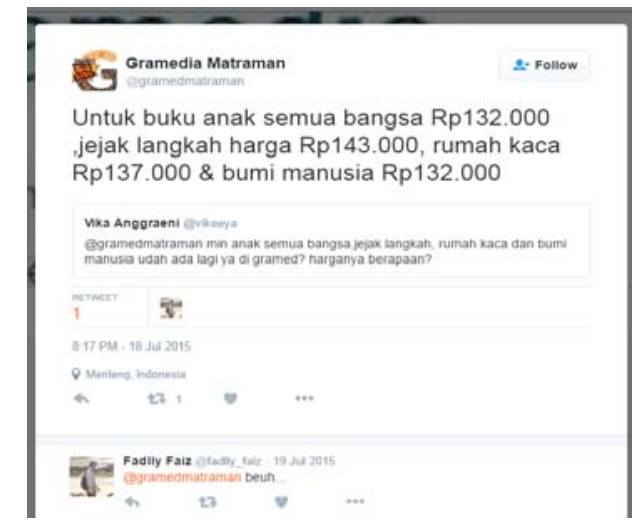

Figure 3 Twitter of Gramedia Matraman (Source: Twitter.com/gramediamatraman, 2016)

The second technique is Humanistic approach technique. This technique is using more humane approach technique. In this technique, the purchasing decision is left entirely to the consumers. Publishers are simply providing various types of children's books such as activities book, story books, and coloring book. It provides information about the benefits and the goodness that available on each product. It can be seen in Figure 4.

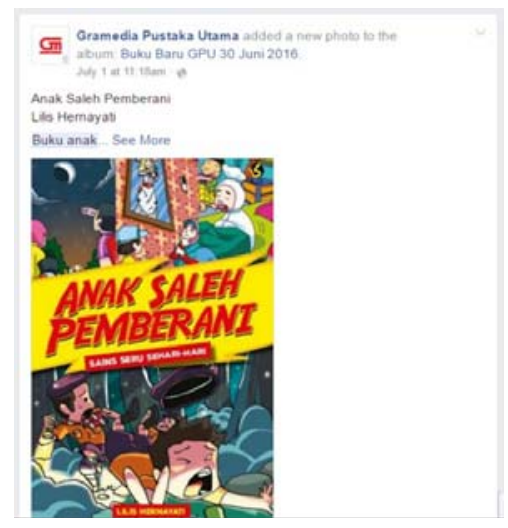

Figure 4 Facebook Promotion at Gramedia Pustaka Utama

(Source: Facebook.com/GramediaPublisher, 2016) 
The third technique is the combination technique between Stimulus-Response and humanistic approach. This technique is the approach technique from the combination of stimulus response and humanistic technique. Publisher in dealing with consumers are conditioned to act that allows customers to be motivated to buy, but the purchasing decision are left entirely to the consumers. The example of this technique can be seen in Figure 5.

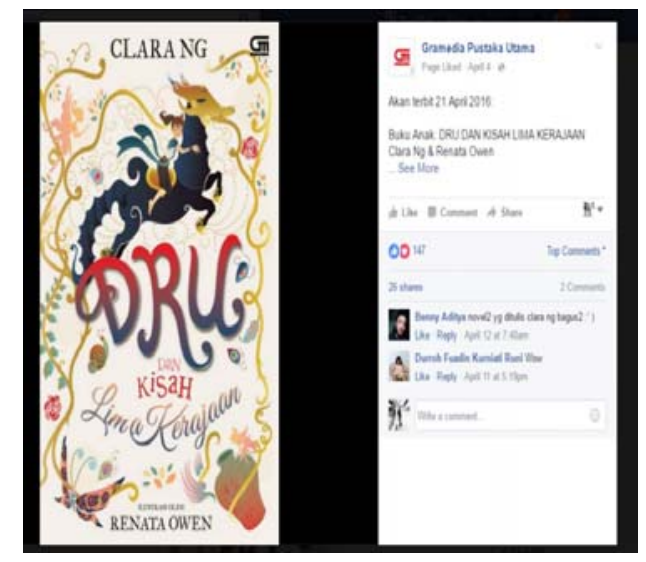

Figure 5 Facebook Decision to Buy at Gramedia Pustaka Utama (Source: Facebook.com/GramediaPublisher, 2016)

The last technique is Persuasive Communication Approach Technique. Johar (2015) has stated that this technique is a persuasive communication approach technique that uses the AIDDAS formula $\mathrm{A}=$ Attention, $\mathrm{I}=$ Interest, $\mathrm{D}=$ Desire, $\mathrm{D}=$ Decision, $\mathrm{A}=$ Action, and $\mathrm{S}=$ Satisfaction

Firstly, the consumers' attention is needed to be raised toward a product in order to a rise their interest, then improvetheir desire to buy the product. Furthermore direct the consumer to take the decision to buy products that suit their needs, with the expectation that the consumers satisfied after purchasing (Rowley, 1998). Before using the AIDDAS formula, publishers must do the following steps. The publisher must pay attention to the consumer with an effective and attractive communications approach. Then study consumers' needs, desires, feelings, nature, characteristics and personality in advance. Publishers also have to listen to the consumers' opinions, and then give conviction about the product's benefits that attract his attention.

Researchers adopt ten principles of effective advertising proposed by O' Guinn (Agus, 2013) for a better guide to made social media promotional content that is interesting and effective to delivered to the receiver. First, social media have to able to attract the attention of consumers as soon as possible. Facebook timeline is the internet pages most visited by consumers. It is started from the posting of social networking consumers themselves, posting fan page, followed by the consumer, until the ad is placed strategically in the Facebook timeline. So the Facebook posting content should be designed to attract the attention of potential customers quickly.

The promotional content shown has to be able to lift the image of the publisher to look positive in the minds of consumers. It is because the entire consumer interactions with the fan-page publisher that can be observed directly by all social networks. Then consumers will generally reluctant to comment or give their consent to the publishers' posting who do not give a positive image to the consumers themselves. The promotional have to look striking. In accordance with the preceding discussion, the Facebook timeline is usually full of messages. Therefore, the promotional content has to be displayed in a unique visual, particularly well with the symbol, photographs, and images to attract the attention of consumers. 
When delivering the message, it has focused in conveying the message. A post should submit one or two main messages only if too many messages to be conveyed that would make consumers think too much and obscure the main goal of promotion. Do not forget to use colors that are attractive and appropriate. The use of an appropriate color to attract the attention of consumers gives positive vibes, and help to lead the consumers' perceptions of the issuer or products. For example, the color used for any promotional children's novel is not the same as the color used for the promotion of novel adult content.

The promotional have to informative. Posts must be able to explain about the product or program being offered by the issuer, or at least convey the vision and image publishers to consumers. It has to be easy to remember. Social media posts are good not only stand out among other posts but also easily remembered by consumers. Besides being easy to remember, the promotional have to memorable. When consumers understand the products and manufacturers via social media posts, the postings are left a good impression on consumers.

The basic idea is 'shows do not tell'. Good social media posts can be understood only through the visual appearance without having to read for the verbal content. Verbal content is only used to add information that consumers are interested in knowing more can get more clear information. Sometimes they use humor and metaphors. Not all the products can be advertised in this way so that the use of humor must be adapted to the context. Humor and modality help to keep posting social media becomes more memorable and easily remembered by consumers.

\section{CONCLUSIONS}

Based on the analysis conducted during the research process concerning children's book marketing communications strategy in social media in an attempt to increase sales can be concluded. Children's book publisher have to perform these marketing communications strategies steps namely identifying message recipient target, determining the purpose of communication, designing message, choosing communication channels, specifying the total budget for communication, deciding the type of marketing communications, measuring communication results, and setting up an integrated marketing communication process.

The publisher has also been conducting communication approaches that make consumers especially the publisher follower to affect the desire to buy the book marketed. The publisher also does a variety of marketing such as launching books or promotional activities, discounts, contests and children's books marketing through social media that can boost children's books sales.

\section{REFERENCES}

Agus, H. (2013). Komunikasi Pemasaran. Jakarta: Erlangga.

Arifin, A. (2006). Ilmu Komunikasi Sebuah Pengantar Ringkas (1 $1^{\text {st }}$ ed.). Jakarta: Rajawali Pers.

Belch, G. E., \& Belch, M. A. (2011). Advertising and Promotion: An Integrated Marketing Communications Perspective ( $9^{\text {th }}$ ed.). McGraw-Hill Education. 
Brison, N. T., Byon, K. K., \& Baker, T. A. (2016). To tweet or not to tweet: The effects of social media endorsements on unfamiliar sport brands and athlete endorsers. Innovation: Management, Policy \& Practice, 18(3). https://doi.org/10.1080/14479338.2016.1237304

Bruner, G. C., \& Pomazal, R. J. (1988). Problem Recognition: The Crucial First Stage of The Consumer Decision Process. Journal of Consumer Marketing, 5(1), 53-63. https://doi.org/10.1108/eb008219.

Cangara, H. (2012). Pengantar Ilmu Komunikasi (2 ${ }^{\text {nd }}$ ed.). Jakarta: PT. Raja Grafindo Persada (Rajawali Perss).

Cheung, C. M. K., \& Lee, M. K. O. (2012). What drives consumers to spread electronic word of mouth in online consumer-opinion platforms. Decision Support Systems, 53(1), 218-225. https://doi.org/http://dx.doi.org/10.1016/j.dss.2012.01.015.

Hassan, S., Zaleha, S., Nadzim, A., \& Shiratuddin, N. (2015). Strategic Use of Social Media for Small Business Based on the AIDA Model. Procedia - Social and Behavioral Sciences, 172, 262 269. https://doi.org/10.1016/j.sbspro.2015.01.363

Hutter, K., Hautz, J., Dennhardt, S., \& Füller, J. (2013). The impact of user interactions in social media on brand awareness and purchase intention: The case of MINI on Facebook. Journal of Product \& Brand Management, 22(5/6), 342-351. https://doi.org/10.1108/jpbm-05-2013-0299

Kartajaya, H. (2010). Konsep Pemasaran. Jakarta: Erlangga.

Kotler, P. (2007). Prinsip-Prinsip Pemasaran (Edisi Ketiga, Jilid 1). Jakarta: Penerbit Erlangga.

Kotler, P., \& Keller, K. L. (2009). Manajemen Pemasaran (13 ${ }^{\text {th }}$ ed.). Jakarta: Erlangga.

Moleong, L. J. (2014). Metodologi Penelitian Kualitatif. Bandung: Remaja Rosda.

Neti, S. (2011). Social media and its role in marketing. International Journal of Enterprise Computing and Business Systems, 1, 1-15. https://doi.org/10.4172/2151-6219.1000203.

Rowley, J. (1998). Promotion and marketing communications in the information marketplace. Library Review, 47(8), 383-387. https://doi.org/10.1108/00242539810239543.

Shimp, T. A. (2003). Periklanan Promosi (5 ${ }^{\text {th }}$ ed.). Jakarta: Erlangga.

Silalahi, U. (2009). Metode Penelitian Sosial. Bandung: Refika Aditama.

Widjaja, A. (2000). Ilmu komunikasi: pengantar studi ( $1^{\text {st }}$ ed.). Jakarta: Rineka Cipta. 